University of Nebraska - Lincoln

DigitalCommons@University of Nebraska - Lincoln

\title{
Regional Advocacy Networks and the Protocol on the Rights of Women in Africa
}

\author{
Melinda Adams \\ James Madison University \\ Alice Kang \\ University of Nebraska - Lincoln, akang2@unl.edu
}

Follow this and additional works at: https://digitalcommons.unl.edu/poliscifacpub

Part of the Political Science Commons

Adams, Melinda and Kang, Alice, "Regional Advocacy Networks and the Protocol on the Rights of Women in Africa" (2007). Faculty Publications: Political Science. 43.

https://digitalcommons.unl.edu/poliscifacpub/43

This Article is brought to you for free and open access by the Political Science, Department of at DigitalCommons@University of Nebraska - Lincoln. It has been accepted for inclusion in Faculty Publications: Political Science by an authorized administrator of DigitalCommons@University of Nebraska - Lincoln. 


\title{
Regional Advocacy Networks and the Protocol on the Rights of Women in Africa
}

\author{
Melinda Adams
}

\author{
James Madison University
}

\section{Alice Kang}

\section{University of Wisconsin-Madison}

While there has been a significant amount of research on transnational feminist activism at the global level, many feminist transnational advocacy networks are mobilizing within world regions. The lack of attention to the regional level has created a considerable imbalance in research on transnational activism. This article's first objective is to define regional advocacy networks (RANs) as a collection of individuals and organizations from the same world region working together toward a common goal. The article's second objective is to explore the conditions under which RANs are influential. We investigate conditions for RAN success through a case study of an African network that helped create one of the world's most progressive treaties on women's rights, the African Union Protocol to the Charter on Human and People's Rights on the Rights of Women in Africa. From an analysis of primary sources and interviews with key participants, we suggest that three factors are crucial for network success: whether a RAN builds alliances with key politicians and civil servants, whether a RAN is able to participate in the decision-making process, and whether a RAN's goals overlap with the target institution's priorities. The broader implication of our study is that scholars seeking to understand the creation of women's rights commitments, the diffusion of women's rights norms, and compliance

The authors like to thank Aili Mari Tripp, Helen Kinsella, John Scherpereel, Renee Buhr, Courtney Hillebrecht, and the editors and reviewers of Politics $\sigma$ Gender for their helpful comments and suggestions. An APSA Small Research Grant and a James Madison University Summer Research Grant supported research in Addis Ababa, Ethiopia.

Published by Cambridge University Press 1743-923X/07 \$15.00 for The Women and Politics Research Section of the American Political Science Association.

(C) 2007 The Women and Politics Research Section of the American Political Science Association.

DOI: $10.1017 / \mathrm{S} 1743923 \times 07000323$ 
with women's rights treaties need to look beyond the international and domestic levels of action to include the regional level in their analyses.

Tn recent years, the study of transnational nonstate actors has established Itself in the field of international relations (Keck and Sikkink 1998; Khagram, Riker, and Sikkink 2002; Tarrow 2005). This research provides a significant corrective to the neorealist and neoliberal assumption of state primacy in international politics. It also demonstrates that transnational feminist networks are agenda setters in arenas such as the United Nations World Conferences. Yet, there is a disconnect between the literature on transnational actors and current directions in transnational organizing. Rather than primarily operating at the global level, many feminist transnational advocacy networks are mobilizing within world regions and are seeking to create, expand, and implement women's rights norms through regional institutions. The lack of research on the regional level has created a considerable imbalance in research on transnational activism.

This article seeks to improve the scholarship on transnational women's rights advocacy by drawing attention to regional advocacy networks (RANs). One objective is to identify what regional advocacy networks are. We define RANs as a collection of individuals and organizations from the same world region working together toward a common goal. Distinct from global networks, RANs are more attuned to local constraints, such as lack of political will from domestic governments and accusations from local actors that women's rights activists represent "foreign" interests. Our second objective is to explore the conditions under which RANs are likely to achieve their goals. We argue that while global dynamics, such as the United Nations' growing recognition of women's rights as human rights, are foundational, more local dynamics are pivotal for RAN success. Drawing on the social movement concept of political opportunity structure, we suggest that RANs are likely to be influential when they build alliances with opinion leaders in states and institutions, when they have the ability to participate in the decision-making process, and when their goals overlap with the target institution's priorities.

To demonstrate the importance of regional networks and understand the conditions under which they are influential, we present a case study of an African RAN that emerged in the late 1990s. Drawing from an analysis of primary sources and interviews with key participants, we explore a RAN's role in creating what is arguably the most progressive international treaty on women's rights, the African Union's (AU) Protocol to the Charter on Human and People's Rights on the Rights of Women in Africa. Adopted 
in 2003, the Protocol on the Rights of Women goes beyond instruments like the Convention on the Elimination of All Forms of Discrimination Against Women (CEDAW) by prohibiting female genital cutting, setting a minimum age of marriage at 18 , and declaring that women have the right to contraception. The Protocol is also the first treaty in the world to guarantee a woman's right to abortion. Concerned with government failure to integrate international women's rights norms and in response to domestic perceptions that women's rights are "Western" impositions, women's rights activists and organizations from the African continent formed a network that accelerated the drafting process, helping to explain the timing of the Protocol's adoption, and expanded its content, helping to account for the Protocol's more radical provisions. The network's success depended on a combination of factors: the alliances the network formed with key African leaders, institutional change within the $\mathrm{AU}$, and institutional priorities to promote gender equality.

This analysis has important empirical and theoretical dimensions. Empirically, intraregional coalitions of women's rights activists are trying a new strategy of regionalizing global norms in Africa, Europe, and Latin America. Theoretically, our emphasis on regional networks refines and extends existing constructivist research on transnational actors and the uptake of international norms. We suggest that scholars seeking to understand the creation of women's rights commitments, the diffusion of women's rights norms, and compliance with women's rights treaties need to look beyond the international and domestic levels of action and include the regional level in their analyses.

\section{PERSPECTIVES ON TRANSNATIONAL WOMEN'S RIGHTS ADVOCACY}

The transnational mobilization of activists - including women's rights activists - has captured the attention of many international relations scholars. In the 1990s, constructivists revived the study of transnational nonstate actors, showing that transnational networks can effect international and domestic change. ${ }^{1}$ Subsequent cross-national statistical research further suggests that transnational actors help states adopt gender mainstreaming policies (True and Mintrom 2001). Transnational

1. Constructivism is an approach in international relations that, in contrast to a neoutilitarian school of thought, emphasizes the social aspects of intemational politics. See Risse (2002). 
networks have also been found to influence international politics. Transnational feminist groups, for example, helped put women's rights issues on the UN agenda (Clark, Friedman and Hochstetler 1998; Joachim 2003). These works demonstrate the limitations of presenting states as solitary actors in world politics.

Recognizing that the power of nonstate actors is not limitless, constructivists have also tried to identify how transnational networks influence states and international institutions. The boomerang model (Keck and Sikkink 1998) and the spiral model (Risse, Ropp, and Sikkink 1999) provide two elegant starting points. Both suggest that transnational advocacy networks help strengthen international human rights norms by persuading foreign governments and international organizations to sanction noncompliant governments. These models tackle limitations in sociological institutionalist work on the spread of a women's rights "world culture" (Berkovitch 1999) by specifying mechanisms of change.

The evidence used to support the boomerang and spiral models' idealtypical portrayals, however, suggests that domestic human rights groups achieve change primarily by alerting audiences in the West. Examining only cases where Western audiences and actors were pivotal is problematic because non-Western transnational networks also influence state politics. Margaret Keck and Kathryn Sikkink do allude to transnational nonstate actors working within world regions such as Latin America (1998, 79, 80, 179-80), but the majority of research on transnational advocacy focuses on global or Western-driven movements (e.g., Tarrow 2005). Aili Tripp (2005) captures the problem well:

The term "transnational feminism" is sometimes used as shorthand for Western involvement in and influence on feminist movements globally. This is only one element of transnational linkages, and one that is increasingly diminishing in importance as movements in the South have begun to claim much of the momentum of feminist and women's rights organizing globally.

Indeed, one study on the number and location of international nongovernmental organizations (INGOs) finds that the percentage of all INGOs in the world that are based in the global South increased from $5 \%$ in 1953 to $23 \%$ in 1993 (Sikkink and Smith 2002). Scholars of transnational activism are beginning to study networks in the South, such as Development Alternatives with Women for a New Era (DAWN) and Women Living Under Muslim Laws (WLUML) (e.g., Moghadam 
2005). Even in these works, the empirical and theoretical significance of regional networks is overlooked.

Feminist scholars raise additional concerns about the representativeness, accountability, and efficacy of transnational advocacy networks. Many argue that power dynamics within transnational networks entail the exclusion of particular groups and class interests; transnational advocacy may represent only the viewpoints of middle-class intellectuals (Desai 2005; Mendoza 2002). How "women's rights" are defined, accordingly, requires dissection to understand whose voices are included and whose are excluded (Grewal and Kaplan 1994; Hesford and Kozol 2005). An additional concern is that transnational activism can lead to unforeseen backlash and complications, a point that we return to in the next section. Last, feminist scholars note that there are trade-offs between mobilizing at the local, grassroots level and mobilizing through transnational, professionalized NGOs (Alvarez 1999). The regional character of more recent feminist movements, however, has not been adequately considered. In sum, research on transnationalism by both international relations and feminist scholars has overlooked the regional level.

\section{A REGIONAL PERSPECTIVE ON TRANSNATIONAL ADVOCACY}

To improve the study of transnational women's rights networks, we call attention to the rise of regional advocacy networks (RANs), a particular kind of transnational advocacy network (TAN). TANs, as defined by Keck and Sikkink $(1998,2)$, are composed of "relevant actors working internationally on an issue, who are bound together by shared values, a common discourse, and dense exchanges of information and services." We define regional advocacy networks as a collection of individuals and organizations from the same world region working together toward a common goal. Like TANs, RANs may include international and domestic NGOs, social movements, and individuals in intergovernmental organizations and national governments.

Emphasizing that many transnational networks are in actuality regional networks is not trivial. While the inclusion of women's rights issues in the UN's agenda may help legitimize women's demands, there are multiple and sometimes contradictory relationships between global and more local efforts to promote women's rights. For example, local women's advocacy groups in Nigeria and an international NGO, Women Living Under Muslim Laws, asked Amnesty International and other 
international human rights organizations to stop petitioning Nigerian government officials in the infamous "stoning" cases in 2002-3 (Imam and Medar-Gould 2003). International petitions angered local officials and gave many Nigerians the impression that local attempts to bring due process to the zina cases masked secular interests. Scholars have discussed similar cases where Western intervention resulted in unintended, negative consequences (see Farrell and McDermott 2005 on the Feminist Majority in Afghanistan).

We do not wish to perpetuate a dichotomy between "Western" and "African" women's rights activists because activists within a single country or world region are not uniformly alike. There are many kinds of feminisms at the local, national, and global levels (Basu 1995). Nor do we wish to portray the relationships between networks as static, zero-sum, or unidirectional. Regional advocacy networks may collaborate well with Western-based networks. Actors in regional networks may feel at the same time that they benefit and suffer from the efforts of other actors and networks. Several scholars have already articulated these points well (Narayan 1997; Sperling, Ferree, and Risman 2001), recognition of which could better inform research on transnational activism.

In contrast to perspectives that emphasize the subjugation of nonWesterners under a global "legal orthodoxy" (Dezalay and Garth 2002), we believe that activists in developing countries adopt legal advocacy tactics based on their own situations and beliefs. Women's activists in developing countries are not just norm takers but are proactive agents responding to local and global contexts. Women's activists within a single world region might perceive common challenges for changing women's lives, creating a starting point for cross-national collaboration. For example, Susanna Wing (2002) echoes a point commonly made on women's activists in Africa when she notes that Malian women are criticized as "Westernized" by their compatriots for mentioning the UN Conference on Women in Beijing. Such criticisms have led many women's rights activists to reconsider the usefulness of drawing on Western or "global" norms.

\section{Conditions for RAN Influence}

Of several important questions that could be asked about regional advocacy (see the conclusion), we focus on the question of the conditions under which RANs are likely to exert influence. Research on transnational mobilization employs the concept of political opportunity structure from social movement theory (e.g., Keck and Sikkink 1998; Khagram, Riker 
and Sikkink 2002; Joachim 2003), which we adopt here. In general, changes in opportunity structures can account for movement outcomes over time and space (McAdam 1996, 27).

One aspect of the political opportunity structure is the relative openness of the political system. The importance of access for nonstate actors has been noted in international relations scholarship. Research on the UN's involvement in the advancement of women consistently points to the importance of women's NGO access to UN structures (Clark, Friedman, and Hochstetler 1998; Winslow 1995). Within international organizations, nonstate actors' ability to participate, determined by official and unofficial rules, can be crucial. Alliances with powerful leaders are a second important aspect of political opportunity (McAdam 1996). Alliances may help outsiders get specific issues on the agenda at international meetings. The presence of alliances may be observed by matching the rhetoric of leaders with that of issue-based advocates. The presence of alliances may also be discovered by examining which countries propose treaty promulgation, amendment, and adoption. Social movement scholars identify the stability of elite alignments as a third aspect of the political opportunity structure. Shifting alliances among elites may provide networks the chance to gain leverage. Relatedly, state actors' unfamiliarity with the issues at hand may create a window of opportunity for nonstate actors. Fourth, institutional priorities and rules also affect the political opportunity structure. Sylvia Walby (2004) argues that the European Union (EU) privileges economic issues and intra-European integration processes, which creates both openings and barriers for activists. The $\mathrm{AU}$, in contrast, has placed greater emphasis on peace, security, and development.

Thus, there are four hypothesized conditions for RAN impact:

1. improved access to the target institution will increase the likelihood of RAN success,

2. alliances with key leaders will increase the likelihood of RAN success,

3. shifting alliances among elites will improve chances for success, and

4. shifting institutional priorities will help improve the likelihood of success.

\section{EXPLORATORY CASE STUDY AND DATA}

In the next section, we use the case of the Protocol on the Rights of Women in Africa to explore the plausibility of these hypothesized conditions for 
success. As we analyze a single case, any conclusions will be suggestive rather than dispositive. Nevertheless, a single case study allows us to trace carefully the process in which RANs seek to influence politics. Primary source documents from the Organization of African Unity (OAU)/AU and the NGOs involved in the campaign serve as the main sources of data for the study. These documents include multiple drafts of the Protocol and markups of draft texts from NGO meetings; OAU and AU reports from experts' and ministerial meetings on the Protocol; transcripts of speeches given at AU- and NGO-sponsored conferences; and reports from NGO meetings. We use these documents to trace the development of the Protocol and to tease out whether and how African women's organizations influenced the text.

We supplement our analysis of primary source materials with data from 10 semistructured interviews with representatives of women's organizations involved in the process. Five respondents respresenting four organizations were directly involved in the RAN (the African Women's Development and Communication Network [FEMNET], the Ethiopian Women Lawyers Association [EWLA], the Inter-African Committee on Traditional Practices Affecting the Health of Women and Children [IAC], and the African Women's Committee on Peace and Development [AWCPD]). Four respondents included staff at the Economic Commission for Africa's (ECA) African Center for Gender and Development, staff at the AU's Gender Directorate, and a former representative to the Pan-African Parliament (see Appendix). The interviews, nine of which were conducted in the summer of 2005 in Addis Ababa and one of which was conducted in the summer of 2006 in Washington, D.C., though small in number, enabled us to check the inferences made from the analysis of documents with actors involved in the process. The interviews were conducted in English. Most interviews lasted about one hour. To meet Institutional Review Board requirements, respondents cannot be identified by name or in a way that compromises their anonymity. We also draw on informal discussions with $\mathrm{AU}$ staff and representatives of women's organizations and on secondary source material.

\section{THE CREATION OF THE PROTOCOL ON THE RIGHTS OF WOMEN IN AFRICA}

In this article, we seek to identify what RANs are and to shed light on the conditions under which they are likely to be influential. The first part of the 
case study examines the process in which the Protocol was created. It then discusses the RAN's influence on the African Union. The last part of the case study assesses the hypothesized conditions for network influence and analyzes which conditions were crucial for RAN influence.

The AU's Assembly of Heads of State and Government adopted the Protocol to the African Charter on Human and Peoples' Rights on the Rights of Women in Africa on July 11, 2003.2 The document covers many women's human rights issues discussed in CEDAW and in the Beijing Platform for Action but, unlike these international documents, the Protocol also reflects specific forms of violations found in parts of Africa. The 32 articles cover political, economic, and cultural rights and address such topics as discrimination, harmful practices, marriage, protection of women in armed conflicts, and health and reproductive rights. Supplementing the 1981 African Charter on Human and Peoples' Rights, the Protocol entered into force on November 25, 2005, 30 days after the deposit of the fifteenth instrument of ratification. As of March 2007, 20 countries had ratified the Protocol. ${ }^{3}$

It took eight years and the sustained attention of a RAN to move from the initial idea of a Protocol to its formal adoption. The RAN brought together lawyers, development experts, and human rights activists who sought to create a regional human rights document that explicitly addressed women's rights, reached or exceeded existing international norms, and specifically dealt with issues faced by women in Africa. Regional organizations in the RAN included the Inter-African Committee on Traditional Practices Affecting the Health of Women and Children (IAC). The IAC is a group of 28 national NGOs whose regional office is in Addis Ababa, Ethiopia. Another important member of the RAN was the African Women's Development and Communication Network (FEMNET), which has national focal points in 22 African countries and a secretariat in Nairobi, Kenya. A key early contributing member of the RAN was Women in Law and Development in Africa (WiLDAF). WiLDAF has a regional office in Harare, Zimbabwe, and has contacts in 31 African states. National organizations like the Ethiopian Women Lawyers Association (EWLA) and the Foundation for Community Development (FDC), which are based in a single country but are concerned with broader regional issues, also participated. Other critical members of the RAN, including Femmes Africa

2. Throughout the narrative, we refer to the OAU before July 2002 and to the AU after July 2002.

3. They include Benin, Cape Verde, Comoros, Djibouti, Gambia, Lesotho, Libya, Malawi, Mali, Mauritania, Mozambique, Namibia, Nigeria, Rwanda, Senegal, Seychelles, South Africa, Togo, and Zambia (African Union n.d.). 
Solidarité (FAS) and Equality Now, were international NGOs that operate at both the global and regional levels.

The seeds of the Protocol were planted at a March 1995 brainstorming seminar that brought together the African Commission on Human and Peoples' Rights (ACHPR) - an intergovernmental organization within the OAU/AU established by the African Charter on Human and People's Rights - and various NGOs that would eventually crystallize into the more cohesive RAN. The seminar was jointly sponsored by the ACHPR and WiLDAF. Forty-four participants came together at the seminar to discuss the need to make the African Charter "more responsive" to women's rights (WiLDAF n.d.). Representatives of WiLDAF and other women's rights organizations argued that the African Charter was insufficient and affected women in contradictory ways (interview with Melinda Adams, Addis Ababa, July 15, 2005; Wandia 2004). They highlighted, for example, the fact that although Article 18(3) states that "the State shall ensure the elimination of every discrimination against women and also ensure the protection of the rights of the woman and the child as stipulated in international declarations and conventions," the Article immediately preceding it could be used to limit the protection of women's rights (OAU 1981). Article 18(2) notes that "the State shall have the duty to assist the family which is the custodian of morals and traditional values recognized by the community" (OAU 1981). Participants claimed that the Charter's respect for traditional values could be used as a basis for justifying the continuation of harmful traditional practices, such as female genital cutting, widowhood rites, and scarification. From the Protocol's inception, regional activists played a critical role in advocating for a women's human rights document.

Although an initial draft of the Protocol was submitted to the OAU in November 1999, it was not until two years later that an OAU experts' meeting was held to discuss it (African Union 2002). These delays were partly a result of the transition from the OAU to the $\mathrm{AU}$, which was marked by high levels of staff turnover. The OAU's first experts' meeting was held in November 2001 in Addis Ababa. Representatives of governments and civil society examined and commented on 27 articles. Participants included official government representatives selected by OAU/AU member states and representatives of organizations that had OAU/AU observer status. The latter could observe but not participate in the meeting's proceedings. Several members of the RAN, including Equality Now, EWLA, FAS, FEMNET, IAC, and WiLDAF, participated as observers. At the end of the 2001 experts' meeting, participants 
reached agreement on all but three articles. Article 6(c), which addressed polygamy, Article 22, which discussed monitoring, and Article 26.5, which covered the process for amending and revising the Protocol, were bracketed for further discussion (OAU 2001).

In 2002, the OAU scheduled a second experts' meeting and a ministerial meeting. It was forced to postpone them, however, due to lack of a quorum. The delay meant that the Protocol could not be placed on the agenda of the inaugural AU summit in Durban in July 2002. Three members of the RAN, the AWCPD, FAS, and the African Centre for the Constructive Resolution of Disputes (ACCORD), organized a meeting in Durban in June 2002 to discuss the delay. This meeting resulted in the Durban Declaration, which called on the $\mathrm{AU}$ to ensure the effective participation of government experts - including women - in the second experts' meeting, and to undertake "expedient adoption, ratification and enforcement of the Draft Protocol"; the Durban Declaration further recommended that the $\mathrm{AU}$ take the necessary steps to ensure that appropriate ministers were able to participate in the scheduled ministerial meeting and that the Protocol conformed to existing regional and international standards on women's human rights (AWCPD 2002). Members of the RAN then circulated the Durban Declaration at the inaugural AU summit.

Concerned about continuing delays and weaknesses in the draft document, Equality Now, FEMNET, and EWLA organized a meeting in Addis Ababa in January 2003 that brought together representatives of a number of African women's rights organizations to mark up the draft Protocol and to discuss how to encourage a quorum at the expert and ministerial meetings. Organizations who were present for this collective markup included the African Centre for Democracy and Human Rights Studies (ACDHRS), Akina Mama Wa Africa, the Association of Malian Women Lawyers (AJM), the Association of Senegalese Lawyers (AJS), Equality Now, EWLA, FAS, FEMNET, WilDAF, and Women's Rights Advancement and Protection Agency (WRAPA). Equality Now played a key role in coordinating the review of the document and in lobbying the $\mathrm{AU}$ to hold the experts' meeting and to involve the RAN in the process (Equality Now 2003, 7). Following the meeting, representatives of the RAN met with AU officials, urging them to organize meetings in March 2003, and lobbied ministries of justice and gender to ensure that the meetings reached a quorum. In March 2003, a second experts' meeting was finally held, which was immediately followed by a ministerial meeting (African Union 2003a). Once again, African women's organizations, led by FAS, convened a presummit meeting to develop an advocacy strategy 
and to lobby representatives of states and the AU during the second experts' meeting.

The RAN's presummit meeting concluded with a reception for experts, which provided activists with an opportunity to talk with them informally immediately before the experts' and ministerial meetings. Members of the RAN attended these meetings as observers and additionally lobbied AU officials to strengthen the Protocol and to ensure that it was in line with existing international standards. The ministers approved the draft Protocol and passed it on to the Executive Council and finally to the AU Assembly. It was then formally adopted by the Assembly Heads of State in July 2003 (African Union 2003b, 2003c). The RAN was pleased with the final document. Equality Now's Faiza Jama Mohamed, for example, stated that "the adoption of this Protocol marks a significant step forward in promoting the rights of women within Africa and we hope lays the groundwork for further gains for all women around the world" (Equality Now 2003, 7).

\section{REGIONAL NETWORKS' INFLUENCE ON THE PROTOCOL}

While it could be suggested that AU member states and international donors made the Protocol on the Rights of Women possible, the case study shows that the women's rights RAN succeeded in creating and influencing this sweeping document. More specifically, success involves influence over several stages of policy activity. As Keck and Sikkink $(1998,25)$ note, networks can influence 1) issue creation and agenda setting, 2) institutional procedures, 3) policy change, 4) the discursive positions of states and organizations, and 5) state behavior. The women's rights RAN to date has exerted influence in the first four of these five stages.

As the preceding discussion indicates, the RAN was an early player in calling attention to the need for a regional women's rights document. But the RAN did more than raise the issue; it also made sure that the issue stayed on the AU's agenda during a period of institutional change marked by significant staff tumover and a large number of policy initiatives in the new organization. The instability of OAU/AU staff made the RAN's role more important, as members of the RAN provided continuity and support for overburdened members of the Gender Directorate. Throughout the delays that occurred during the transition, it was the RAN, not member states or Western actors, that pressured the $\mathrm{AU}$ to move ahead with the Protocol.

The RAN not only influenced the OAU/AU's agenda but also affected its institutional procedures. From the beginning, the RAN pressured the 
OAU to include nonstate actors in the working group that wrote the first draft of the Protocol. The RAN also lobbied for the inclusion of civil society organizations in experts' meetings. When nonstate actors could not officially participate in meetings, they attended as observers or, when that was not possible, held parallel presummit meetings that allowed them to lobby key state and regional decision makers.

Close textual analysis suggests that the RAN played a critical role in shaping the content of the Protocol and in ensuring that it reached or surpassed existing international women's rights norms. Members of the RAN, including WiLDAF and the ACDHRS, were part of the initial working group that met several times in 1998 and 1999 to draft the first iteration of the Protocol, which was submitted to the OAU in 1999. At the January 2003 meeting organized by Equality Now, members of the RAN developed a collective markup of the Protocol, showing where it was weak and/or fell below international standards. Women's organizations had a direct impact on at least 12 articles. While definitions of violence against women and discrimination against women in the Protocol draw from UN women's rights treaties (Ebeku 2004), the provisions on abortion, contraception, and the rights of widows, the elderly, and disabled are innovative. Women's organizations suggested that member states should be required to enact and enforce laws to prohibit violence against women, which includes "unwanted or forced sex" (Article 4) (Equality Now 2003). This is in the final document but was not in the original November 1999 draft. The final version of the Protocol calls for the prohibition of all forms of female genital mutilation "through legislative measures backed by sanctions," whereas the 1999 version does not specifically require legal action (Article 5). The final version of Article 9 explicitly suggests that states use "affirmative action" to ensure equal opportunity for women in the political life of their countries. In addition to suggesting changes to existing clauses, women's organizations also added new clauses. Women's organizations inserted new clauses on equal representation and on the reform of discriminatory laws (Article 8). They also were in favor of adding five articles guaranteeing special provisions for widowed, elderly, and disabled women (Articles 20, 21, 22, 23, and 24) (Equality Now 2003). There is little evidence that member states or Western actors initiated these changes.

The RAN's efforts to influence particular articles in the Protocol did encounter resistance. The RAN initially asked that the Protocol set restrictions on polygamy, but after two days of debates, the AU's experts 
and women's rights activists came to a compromise and agreed on a clause stating that monogamy is the preferred form of marriage (Article 6[c]). Polygamy, and marriage more generally, is an issue that African women's rights activists have found particularly difficult to contest at the domestic level. In contrast, articles on improving women's political representation and guaranteeing rights to contraception and abortion were less controversial. The issues that most challenge women's rights activists on the continent are not necessarily the same issues that challenge women's rights activists in other world regions.

The RAN not only influenced the Protocol but also targeted other issues in the AU. This broader work influenced the discursive positions of states and the $\mathrm{AU}$ on a wide array of gender equality issues. During the transition from the $\mathrm{OAU}$ to the $\mathrm{AU}$, the RAN lobbied regional leaders to include a commitment to gender equality as a central principle in the AU's Constitutive Act (Article 4[1]). This commitment demonstrates the potential significance of discursive positions. Once leaders had enshrined gender equality as one of the AU's constitutive values, activists invoked Article $4(1)$ of the Constitutive Act as they lobbied for specific policies. Using this tactic, activists won leaders' commitment to gender parity in $\mathrm{AU}$ decision-making positions, to a gender quota for delegations to the Pan-African Parliament, to the Protocol, and to the Solemn Declaration on Gender Equality in Africa. The Solemn Declaration, adopted by the AU Assembly in 2004, calls on states to submit annual reports on their progress toward achieving gender equality. It also requires the $\mathrm{AU}$ Commission to prepare a report each year describing progress made in this area at the national and regional levels.

The RAN also influenced the discursive positions of specific states, pressuring them to adopt the Protocol, as well as other agreements such as the Solemn Declaration. Many of the organizations that participated in the RAN that pushed for the adoption of the Protocol formed a coalition - Solidarity for African Women's Rights (SOAWR) - to pressure member states to ratify and implement it. To date, 43 countries have signed the Protocol and 20 have ratified it. For those states that have ratified the Protocol, it is a legally binding treaty. The reality, though, is that the Protocol has weak enforcement mechanisms, and state compliance is by no means guaranteed. Ratifying international documents does not necessarily change state behavior. It does, however, provide activists with standards to which they can seek to hold states accountable and may serve as a step toward changing state behavior. 


\section{CONDITIONS FOR REGIONAL NETWORK INFLUENCE}

The proceeding section outlined the RAN's impact in four stages of policy activity. The objective of this section is to explain how the RAN was able to have this influence, particularly as it had not been as successful in the past. Earlier, we hypothesized that the relative openness of the political system, alliances with powerful leaders, stability of elite alignments, and institutional priorities influence whether movements succeed or fail. In the case of the Protocol, we find that the political opportunity structure provided critical openings that activists effectively utilized to pressure states and the OAU/AU to adopt the Protocol. In particular, elite alliances, openings created by the transition from the $\mathrm{OAU}$ to the $\mathrm{AU}$, and a close match between the RAN's goals and the AU's priorities contributed to the RAN's success.

\section{Political Alliances}

Activists formed critical alliances with key African leaders, which played an important role in the RAN's success. Ambassadors, foreign ministers, and heads of state and government who draft and adopt $\mathrm{AU}$ policies are overwhelmingly men. The RAN, therefore, needed to identify leaders who would support women's rights at AU summits. Members of the RAN worked closely with regional opinion leaders, such as South Africa's Thabo Mbeki and Senegal's Abdoulaye Wade, to achieve their goals. After attending the women's presummit meeting in Durban, for example, Wade proposed the gender parity provision that called for the selection of equal numbers of women and men to the AU Commission. Discussing Wade's role, a FAS publication noted that Wade "used his good offices to mobilize his peers to actively promote the objective of gender equality. As a result of his sensitive advocacy, the President did not face any opposition from other African leaders" (FAS 2004, 30). In 2003, Mbeki, who was then president of the AU, oversaw the election of equal numbers of women and men to the AU Commission and the adoption of the Protocol. At the 2004 summit, Mbeki called for the reintroduction of reporting mechanisms that had been dropped from the Solemn Declaration.

Discussing the success of African women's networks in lobbying AU opinion leaders, a staff member of the ECA's African Center for Gender and Development noted: 
It was because they were very astute. These are women who are very experienced, and they are politicians. They are politicians so they are strategic and they lobbied individuals and ... identified the key players among the heads of state, they identified them. They lobbied the Chairman and they lobbied the regional leaders, they lobbied the opinion makers in each region. They got their support of key people at the highest levels (interview with Adams, Addis Ababa, July 27, 2005).

A former EWLA staff member similarly highlighted the importance of lobbying key players:

At every summit, when women's groups go to $\mathrm{AU}$ summits and they lobby in the corridors, they lobby the ambassadors, they really made a lot of effort over several years and that backdoor lobbying, that backdoor advocacy, somehow delivered at the end of the day. And in fact this was initiated by the Senegalese president. And in fact, you know, both were, the presidents who proposed and supported it, the Senegalese president and the South African president, they are also committed... But the thing is who initiated it and it has been, you know, it has been pushed by women, women's groups. But also this is not to minimize the credit that should be given to the heads of state (interview with Adams, Addis Ababa, July 25, 2005). ${ }^{4}$

Women's rights activists in the RAN sought out and gained the ears of individuals who had demonstrated a commitment to women's rights and whose opinions carried weight within the region. This strategy and collaboration represents a departure from the past where contact between women's rights activists and regional leaders was more limited.

\section{Openness of the Political System}

The transition from the OAU to the AU opened opportunities for changing institutional policies and norms. Discussing why the AU has taken such a progressive stance on gender issues - at least at the policy level - a staff member at the AU's Gender Directorate compared the AU's progress on gender issues to that of South Africa and Rwanda (interview with Adams, Addis Ababa, July 19, 2005). The South African constitution is widely recognized as one of the most progressive in the world on gender equality. Currently, Rwanda has the highest percentage of female legislators in the world. Both countries achieved these changes following

4. FAS awarded Wade and Mbeki the first African Gender Award in 2005 for their support of gender equity measures within the AU (FAS 2005). 
conflict and regime change. Scholars have highlighted that political change has frequently provided openings for women to challenge patriarchal structures and to increase women's representation (e.g., Goetz and Hassim 2003; Seidman 1999; and Tripp 2003). Drawing on national experiences and women's success in demanding greater representation in Mozambique, Rwanda, South Africa, Uganda, and elsewhere, activists took advantage of the transition from the $\mathrm{OAU}$ to the $\mathrm{AU}$ to secure greater commitments to women's rights. Activists emphasize that the creation of the $\mathrm{AU}$ was critical to the development of regional gender equity policies since it is easier to change norms and policies when institutional rules and practices are in flux.

The decision to launch a new regional organization, which was announced in 1999 at an Extraordinary OAU Summit in Sitre, Libya, provided the RAN with an opening to push for a stronger commitment to gender equality. The 2002 Durban Declaration, for example, states that women's organizations were "convinced that African women must seize the opportunity provided by the historical moment of the launching of the African Union to ensure their full and effective participation in its operationalisation" (AWCPD 2002). In addition, proceedings from the 2003 presummit meeting in Maputo state that the transition from the $\mathrm{OAU}$ to the $\mathrm{AU}$ "provided the opportunity for women's organisations and networks to meet and discuss the pertinent issues facing gender and women on the Continent and to develop strategies and recommendations to address these issues within the newly formed structure" (FDC 2003).

\section{Institutional Priorities}

The compatibility of the RAN's goals and the AU's institutional priorities further contributed to the RAN's influence. The AU's desire to represent the people of the continent translated into policies that offered civil society greater input into $\mathrm{AU}$ policies. Discussing the more cooperative relationship between the $\mathrm{AU}$ and civil societal groups, a staff member at the IAC stated:

The Gender Directorate invited civil society about a month and a half ago to input into this Solemn Declaration. African Heads of State made a Solemn Declaration supporting gender and we decided that if we just leave them after signing that paper, they are not likely to implement it. We'd better design guidelines for implementation for them and tools to monitor the 
implementation. And [the] African Union invited civil society. We were part of that process to design guidelines to monitor Heads of State implementing the Solemn Declaration on gender. That is a change. That's a shift. The OAU probably would not have invited you. You had to push yourself into OAU. Remember we drafted a Convention and pushed ourselves into the mouth of OAU. But now the AU on their own does the invitation and the consultation with civil society. There is a great change. There is a great shift. They consult with us and they take what we have said into consideration. We sat with them deciding how to monitor. And that was a big thing. (Interview with Adams, Addis Ababa, July 15, 2005)

The AU established a Gender Directorate that frequently holds consultations on $\mathrm{AU}$ gender policies and invites representatives of civil society to participate in these meetings. The Gender Directorate has also collaborated with NGOs to cosponsor conferences. The $\mathrm{AU}$ and SOAWR, for example, jointly sponsored a conference on the ratification and domestication of the Protocol in September 2005. Though Winnie Byanyima, the head of the AU's Gender Directorate, specifically refers to the Solemn Declaration, her comments are equally relevant to the Protocol:

The third and last point I wish to stress is the critical role of civil society in this process. The SD is the labour of love of African women's organisations. Women spent many years asking African leaders to address their concerns and to include them in decision-making. That is why in the first three ... years of its existence, the $\mathrm{AU}$ has made land-mark decisions that have made it a global leader in the promotion of gender equality. To maintain and even increase the momentum towards gender equality, civil society has to continue the critical role it has played in the past (Byanyima 2005).

To distinguish itself from its predecessor and to demonstrate its commitment to representing the people of Africa rather than just its governments, the AU has sought to work more closely with civil society organizations and to improve its reputation on human rights. The goals of the RAN, therefore, overlapped with those of the $\mathrm{AU}$, which enhanced the RAN's influence.

Alternative narratives would suggest that member states and Western donors played a more important role than did the women's rights network and that international norms of women's rights were essential. Focusing solely on state actors does not explain the timing or the expansive content of the Protocol. Indeed, state representatives to the AU expressed reservations against several articles at the March 2003 ministerial meeting. While the RAN received support from international 
groups, such as the International Commission of Jurists, it was better placed to addresses controversial issues, such as polygamy, abortion, and female genital cutting, which pose difficulties for external activists accused of imposing "Western" values. Without the RAN, Western-based networks and international norms could not have gone very far.

The question we have sought to answer is why the RAN was able to influence the creation of such a document. We argue that the political opportunity structure affects whether RANs will be influential. Specifically, the case study suggests that RANs will be influential when they have allies within states, when they have the ability to participate in the decisionmaking processes of the institutions they seek to influence, and when their goals match with the target institution's priorities. In this case study, shifting alliances among elites was not a significant factor.

None of this would have mattered, however, if the RAN did not have strong national and regional women's organizations upon which to build. The existence of national-level women's organizations enabled the RAN to coalesce quickly to take advantage of the shifting opportunity structure. The case study suggests that a propitious political opportunity structure is important. For this to matter, though, actors must mobilize to seize these opportunities. This is a single case study, and its conclusions are suggestive.

\section{CONCLUSIONS AND IMPLICATIONS: REGIONAL ADVOCACY BEYOND THE AFRICAN CASE}

This article has two major objectives. First, we suggest that regional advocacy networks (RANs) are emerging as distinct, powerful players in contemporary world politics. Our focus on regional-level advocacy provides concrete causal linkages lacking in sociological institutionalist research and tackles the lack of research on non-Western actors in a fairly well-established literature on transnational activism. Second, we argue that activists within the African continent took advantage of a propitious political opportunity structure to pressure states to adopt the Protocol. The transition from the $\mathrm{OAU}$ to the $\mathrm{AU}$ provided activists the opportunity to push for stronger gender equality measures. RANs mobilized quickly following the announcement of the transition to secure a commitment to gender equality within the AU's Constitutive Act. They then drew on this commitment to pressure states to adopt specific gender equality measures such as the Protocol. The transition 
also opened additional channels for nonstate actors to participate in regional decision making.

The implications of this research go beyond the African context. A glance at various arenas of contemporary world politics shows that RANs are emerging in different regions and under different regional opportunity structures. In Europe, a RAN campaigned for gender equality within the European Union by using access to EU institutions to expand gender equality rights. Although individuals do not have direct access to the European Court of Justice (ECJ), a women's RAN works with domestic courts to refer gender equality cases to the ECJ (Tarrow 2005, 152). This strategy has been quite effective: Between 1970 and the late 1990s, the ECJ reviewed 177 cases involving gender equality (Cichowski 2001, 122; Tarrow 2005, 153).

In Latin America, women's activists have organized a series of informal, intraregional meetings called Encuentros (encounters), which bring together women to discuss the state of feminism and women's activism in the region. These meetings provide an opportunity for activists to participate in "periodic regional conversations" on such topics as the state of feminism in Latin America, the value of autonomy, and who should be allowed to participate in the meetings (Alvarez et al. 2003, 540). In contrast with the meetings organized by African women's RANs, the focus of the Encuentros is not on influencing national and regional policies.

A RAN in Latin America also contributed to the adoption of the 1994 Convention on the Prevention, Punishment and Eradication of Violence against Women. The Convention has raised awareness about violence against women and prompted the revision and adoption of national laws. At the same time, there is little data that indicates that domestic violence is actually declining in Latin America. Moreover, "some countries of the region have treated the ratification of the Convention as a 'destination' and not as a "point of departure" (Inter-American Commission of Women 2001, 18). The Convention demonstrates some of the strengths and weaknesses of regional women's rights documents and highlights that adoption and ratification are just two steps in a long process of changing behaviors.

Future research can more fully interrogate why RANs emerge when they do and whether regional networks help countries comply with women's rights agreements and domestic policies on women's rights. This will necessitate a closer and more systematic examination of the relationships among domestic state policies, national women's organizations, and 
regional advocacy networks. Nevertheless, our article demonstrates the importance of a regional advocacy network in directing regional-level awareness of women's rights. Women's advocates in Africa and elsewhere are trying a new strategy: In addition to domesticating international norms, they are regionalizing them.

\section{REFERENCES}

African Union. 2002. "Decision on the Draft Protocol to the African Charter on Human and Peoples' Rights Relating to the Rights of Women in Africa." July 5-8. CM/ Dec.39 (LXXIV).

African Union. 2003a. "Draft Protocol to the African Charter on Human and Peoples' Rights on the Rights of Women in Africa." March 28. MIN/WOM/RTS/ DRAFT.PROT(II)Rev. 5.

African Union. 2003b. "Decision on the Draft Protocol to the African Charter on Human and Peoples' Rights Relating to the Rights of Women." July 10-12. Assembly/AU/ Dec.19 (II).

African Union. 2003c. "Protocol to the African Charter on Human and Peoples' Rights on the Rights of Women in Africa." July 11. http://www.achpr.org/english/_info/ women_en.html (May 15, 2007).

African Union. N.d. "List of Countries Which Have Signed, Ratified/Acceded to the Protocol to the African Charter on Human and People's Rights on the Rights of Women in Africa." http://www.africa-union.org/root/au/Documents/Treaties/List/ Protocol\%20on\%20the\%20-Rights\%20of\%20Women.pdf (May 15, 2007).

AWCPD (African Women's Committee on Peace and Development). 2002. "Durban Declaration on Mainstreaming Gender and Women's Effective Participation in the African Union." http://www.fasngo.org/en/whatnew/doc/pressjun02\%20decla\%20e.pdf (May 15, 2007).

Alvarez, Sonia. 1999. "Advocating Feminism: The Latin American Feminist NGO 'Boom."' Intermational Feminist Joumal of Politics 1 (2): 181-209.

Alvarez, Sonia, et al. 2003. "Encountering Latin American and Caribbean Feminisms." Signs: Joumal of Women in Culture and Society 28 (2): 537-79.

Basu, Amrita, ed. 1995. The Challenge of Local Feminisms: Women's Movements in Global Perspective. Boulder, CO: Westview Press.

Berkovitch, Nitza. 1999. From Motherhood to Citizenship: Women's Rights and International Organizations. Baltimore: Johns Hopkins University Press.

Byanyima, Winnie. 2005. "Intervention." African Union Commission's Technical Consultative Meeting on the Solemn Declaration on Gender Equality in Africa. http://www.africa-union.org/Gender/SOLEMN/Home.htm (May 15, 2007).

Cichowski, Rachel. 2001. "Judicial Rulemaking and the Institutionalization of European Union Sex Equality Policy." In The Institutionalization of Europe, ed. Alec Stone Sweet, Wayne Sandholtz, and Neil Fligstein. Oxford: Oxford University Press, 113-36.

Clark, Ann Marie, Elisabeth Friedman, and Kathryn Hochstetler. 1998. "The Sovereign Limits of Global Civil Society: A Comparison of NGO Participation in UN World Conferences on the Environment, Human Rights, and Women." World Politics $51(1): 1-35$.

Desai, Manisha. 2005. "Transnationalism: The Face of Feminist Politics Post-Beijing." International Social Science Joumal 57 (2): 319-30. 
Dezalay, Yves, and Bryant Garth, eds. 2002. Global Prescriptions: The Production, Exportation and Importation of a New Legal Orthodoxy. Ann Arbor: University of Michigan Press.

Ebeku, Kaniye. 2004. “A New Hope for African Women: Overview of Africa's Protocol on Women's Rights." Nordic Journal of African Studies 13 (3): 264-74.

Equality Now. 2003. "African Regional Consultation Meeting on the Draft Protocol on the Rights of Women." January 4-5, Addis Ababa.

Farrell, Amy, and Patrice McDermott. 2005. "Claiming Afghan Women: The Challenge of Human Rights Discourse for Transnational Feminism." In Just Advocacy? Women's Human Rights, Transnational Feminisms, and the Politics of Representation, ed. Wendy Hesford and Wendy Kozol. New Brunswick, NJ: Rutgers University Press, $33-55$.

FAS (Femmes Africa Solidarité). 2004. Women Building Peace in Africa: The Case of the African Women Committee on Peace and Development. Geneva.

FAS (Femmes Africa Solidarité). 2005. "African Gender Award." http://www. africangenderawards.org/ (May 15, 2007).

FDC (Foundation for Community Development). 2003. "Report on the Proceedings." Women's Pre-Summit Meeting. Maputo.

Goetz, Anne Marie, and Shireen Hassim, eds. 2003. No Shortcuts to Power: African Women in Politics and Policy Making. New York: Zed Books.

Grewal, Inderpal, and Caren Kaplan, eds. 1994. Scattered Hegemonies: Postmodemity and Transnational Feminist Practices. Minneapolis: University of Minnesota Press.

Hesford, Wendy, and Wendy Kozol, eds. 2005. Just Advocacy?: Women's Human Rights, Transnational Feminisms, and the Politics of Representation. New Brunswick, NJ: Rutgers University Press.

Imam, Ayesha, and Sindi Medar-Gould. 2003. "Please Stop the International Amina Lawal Protest Letter Campaigns - For Now." May 2. Women Living Under Muslim Laws News and Views. http://www.wluml.org/english/newsfulltxt.shtml?cmd\%5B157\%5D=x-1574556 (May 15, 2007).

Inter-American Commission of Women. 2001. "Second Biennial Report of the InterAmerican Commission of Women on Compliance with Resolution AG/RES. 1456 (XXVII-O/97), "Promotion of the Inter-American Convention on the Prevention, Punishment, and Eradication of Violence Against Women, Convention of Belém Do Pará." May 3. OEA/Ser.G, CP/doc.3440/01 rev. 1.

Joachim, Jutta. 2003. "Framing Issues and Seizing Opportunities: The UN, NGOs, and Women's Rights." International Studies Quarterly 47 (2): 247-74.

Keck, Margaret, and Kathryn Sikkink. 1998. Activists Beyond Borders: Advocacy Networks in International Politics. Ithaca, NY: Cornell University Press.

Khagram, Sanjeev, James Riker and Kathryn Sikkink, eds. 2002. Restructuring World Politics: Transnational Social Movements, Networks, and Norms. Minneapolis: University of Minnesota Press.

McAdam, Doug. 1996. "Conceptual Origins, Current Problems, Future Directions." In Comparative Perspectives on Social Movements: Political Opportunities, Mobilizing Structures, and Cultural Framings, ed. Doug McAdam, John McCarthy, and Mayer Zald. New York: Cambridge University Press, 23-40.

Mendoza, Breny. 2002. "Transnational Feminisms in Question." Feminist Theory 3 (3): 295-314.

Moghadam, Valentine. 2005. Globalizing Women: Transnational Feminist Networks. Baltimore: Johns Hopkins University Press.

OAU (Organization of African Unity). 1981. "African Charter on Human and Peoples' Rights." http://www.achpr.org/english/_info/charter_en.html (May 15, 2007). 
OAU (Organization of African Unity). 2001. "Draft Protocol to the African Charter on Human and Peoples' Rights on the Rights of Women in Africa (as adopted by the Meeting of Government Experts in Addis Ababa on 16 November 2001)." November 22. CAB/LEG/66.6/Rev.1.

Narayan, Uma. 1997. Dislocating Cultures: Identities, Traditions, and Third-World Feminism. New York: Routledge.

Risse, Thomas. 2002. "Transnational Actors and World Politics." In Handbook of Intemational Relations, ed. Walter Carlsnaes, Thomas Risse, Beth Simmons. Thousand Oaks, CA: Sage, 255-74.

Risse, Thomas, Stephen Ropp, and Kathryn Sikkink, eds. 1999. The Power of Human Rights: International Norms and Domestic Change. Cambridge: Cambridge University Press.

Seidman, Gay. 1999. “Gendered Citizenship: South Africa's Democratic Transition and the Construction of a Gendered State." Gender F Society 13 (3): 287-307.

Sikkink, Kathryn, and Jackie Smith. 2002. "Infrastructures for Change: Transnational Organizations, 1953-93." In Restructuring World Politics: Transnational Social Movements, Networks, and Norms, ed. Sanjeev Khagram, James Riker, and Kathryn Sikkink. Minneapolis: University of Minnesota, 24-46.

Sperling, Valerie, Myra Marx Ferree, and Barbara Risman. 2001. "Constructing Global Feminism: Transnational Advocacy Networks and Russian Women's Activism." Signs: Joumal of Women in Culture and Society 26 (4): 1155-86.

Tarrow, Sidney. 2005. The New Transnational Activism. Cambridge: Cambridge University Press.

Tripp, Aili. 2003. "Women in Movement: Transformations in African Political Landscapes." Intemational Feminist Journal of Politics 5 (2): 233-55.

Tripp, Aili. 2005. "Regional Networking as Transnational Feminism: African Experiences." Feminist Africa 4. http://www.feministafrica.org/04-2005/2level.html (May 15, 2007).

True, Jacqui, and Michael Mintrom. 2001. "Transnational Networks and Policy Diffusion: The Case of Gender Mainstreaming." International Studies Quarterly 45 (1): 27-57.

Walby, Sylvia. 2004. "The European Union and Gender Equality: Emergent Varieties of Gender Regime." Social Politics 11 (1): 4-29.

Wandia, Mary. 2004. "Rights of Women in Africa: Launch of Petition to the African Union." June. http://www.choike.org/nuevo_eng/informes/1944.html (May 15, 2007).

Wing, Susanna. 2002. "Women Activists in Mali: The Global Discourse on Human Rights." In Women's Activism and Globalization: Linking Local Struggles and Transnational Politics, ed. Nancy Naples and Manisha Desai. New York: Routledge, $172-88$.

WiLDAF (Women in Law, and Development in Africa). N.d. "The African Charter on Human and Peoples' Rights and the Additional Protocol on Women's Rights." WiLDAF News.

Winslow, Anne, ed. 1995. Women, Politics, and the United Nations. Westport, CT: Greenwood.

\section{APPENDIX: LIST OF INTERVIEWS}

Three staff members, Inter-African Committee on Traditional Practices Affecting the Health of Women and Children, Addis Ababa, 15 July 2005. Staff member, Gender Directorate, African Union, Addis Ababa, 19 July 2005. 
Staff member, African Center for Gender and Development (ACGD), Economic Commission for Africa (ECA), Addis Ababa, 19 July 2005.

Staff member, Conference on Security, Stability, Development and Cooperation/Civil Society and Diaspora Directorate (CSSDC/CSDD), African Union, Addis Ababa, 21 July 2005.

Consultant, African Union, Addis Ababa, 21 July 2005.

Member, Board of Trustees, African Women's Development and Communications Network (FEMNET), Addis Ababa, 22 July 2005.

Former staff member, Ethiopian Women Lawyers Association (EWLA), Addis Ababa, 25 July 2005.

Staff member, Gender Directorate, African Union, Addis Ababa, 26 July 2005.

Staff member, African Center for Gender and Development (ACGD), Economic Commission for Africa (ECA), Addis Ababa, 27 July 2005.

Former representative to the Pan-African Parliament, Washington, DC, 22 June 2006. 